\section{Changes in Sugar Content and Sucrose Synthase Enzymes during Fruit Growth in Eggplant (Solanum melongena L.) Grown on Different Polyethylene Mulches}

\author{
Heeock Boo \\ Department of Biology, College of Nature Science, Chosun University, 375 \\ Seosuk-Dong, Gwangju-City 501-759, South Korea
}

\author{
Honggi Kim \\ Jeonnam Bio Control Center, Gokseong 516-942, South Korea
}

\author{
Hyunhwa Lee ${ }^{1}$ \\ Department of Biology, College of Nature Science, Chosun University, 375 \\ Seosuk-Dong, Gwangju-City 501-759, South Korea
}

Additional index words. sucrose metabolism, sink activity, climatic condition

\begin{abstract}
This study clarified the role of the key enzymes [sucrose phosphate synthase (SPS), sucrose synthase (SS)] in the sucrose synthesis of eggplant (Solanum melongena L.) cultured on different polyethylene mulches. Sugar concentration in fruit and SPS and SS activities in leaf and fruit were measured during the different fruit development stages. Total sugar concentration was the highest on the reflective mulches throughout all the developmental stages of eggplant and followed by the white, the black, and transparent mulches. The concentrations of all three individual sugars (sucrose, glucose, and fructose) increased during fruit development on all four polyethylene mulches. Although no specific pattern in enzyme activities of leaf and fruit related to the sugar accumulation of eggplant fruit was observed, the reflective and white mulches triggered higher sucrose synthase enzyme activities than did the black and transparent mulches.
\end{abstract}

Eggplant (Solanum melongena L.), as a member of the Solanaceae family, mostly demands high temperature and light during its growth (Krug, 1991; Messiaen, 1989). It is usually grown in open fields during summer and in greenhouses during winter. In particular, lack of light in cultivating eggplant may result in poor fruit quality (Sezgin, 2007). Therefore, different reflective film mulches are usually used to enhance lighting. Black, white, and reflective film mulches in vegetable crops can improve their yield as well as quality (Costello, 1995).

Depending on the mulch color and the local climatic conditions, microenvironments around plants can be altered to improve crop growth and yield (Decoteau et al., 1990). Dark-colored films increase soil temperature through greater heat absorbance. Lighter colors, however, reflect more sunlight, minimize changes in soil temperature, and increase light intensity around the plant canopy (Orzolek and Murphy, 1993). Reflective mulches can induce higher rates of photosynthesis by increasing the intensity of

Received for publication 19 May 2009. Accepted for publication 8 Mar. 2010.

This study was supported (in part) by research funds from Chosun University (2006).

${ }^{1}$ To whom reprint requests should be addressed; e-mail papaya@chosun.ac.kr. selected active light wavelengths in the lower canopy depending on the plant density (Porter and Etzell, 1982). Black and white film mulches are widely used to manipulate soil temperature. They have been found to aid plant growth with diverse climatic conditions (Albregts and Chandler, 1992; Brown et al., 1992; Porter and Etzell, 1982).

Fruit growth requires an increase in sink activity, which is provided by activating carbohydrate metabolism. Sucrose synthase (SS) and sucrose phosphate synthase (SPS) are enzymes that affect sucrose metabolism and that are associated with the developmental processes of the sink organ (Balibrea et al., 1996; Islam et al., 1996; Kim et al., 2003; Sung et al., 1994). The application of sugarinduced activity of SS and changes in the concentration of sucrose in the sink organ are known to control SS activity (Claussen et al., 1986). These findings suggest that SS activity is regulated by sucrose. This study, therefore, was carried out to clarify the distribution of sugars and related sucrose enzymes at four developmental stages of the eggplant fruit cultured on different polyethylene mulches.

\section{Materials and Methods}

Plant material and growing conditions. Japanese-type eggplant (Solanum melongena L. cv. Chikuyou) seedlings were planted onto beds mulched with black, white, reflective (silverized film), and transparent (control) films ( $0.1 \mathrm{~mm}$ thick) as polyethylene mulches. The beds consisted of three rows $9 \mathrm{~m}$ long and $110 \mathrm{~cm}$ wide. The rate of light reflection was $42 \%$ to $48 \%$ for the reflective film, $7 \%$ to $8 \%$ for the black film, $16 \%$ to $19 \%$ for the white film, and $11 \%$ to $12 \%$ for the transparent film. The seedlings were grown in a greenhouse at a soil temperature of $25 / 20{ }^{\circ} \mathrm{C}$ day/night. Planting density was $80 \mathrm{~cm}$; only plants from the central rows were harvested for analysis. Each experiment was designed as a randomized complete block with three replicates.

Sugar analysis. To analyze the sugar content, fruit samples were collected at different development stages on the basis of fruit length, ranging from 2 to $3 \mathrm{~cm}$ to 18 to $20 \mathrm{~cm}$ in length. Samples of fruit tissue $(10 \mathrm{~g})$ were macerated in a mortar with acid-purified sand and $80 \%$ ethanol. After centrifugation, residues were extracted and centrifuged twice using $30 \mathrm{~mL}$ ethanol at $12,000 \times g$ for 10 min. The extracts were filtered and evaporated; the total volume of each sample was adjusted to $10 \mathrm{~mL}$ with distilled water. Sugar (sucrose, glucose, and fructose) composition and concentration of samples were analyzed using high-performance liquid chromatography. Before injection, $5 \mathrm{~mL}$ of the sample was passed through $\mathrm{C}_{18}$ Sep-Pak cartridge (Waters, Milford, MA) and then further filtered through $0.45 \mu \mathrm{m}$ Acrodisc prefilter (Pall Corporation, USA). The sugars were eluted onto a Waters Sugar-Pak ${ }^{\text {TM }}$ I column $(6.5 \times 300 \mathrm{~mm})$ isocratically with a mobile phase of water at a flow rate of $0.5 \mathrm{~mL} \cdot \mathrm{min}^{-1}$. The eluate was monitored using a refractive index detector. Each experiment was conducted in triplicate and involved combined extracts of three different eggplant fruits.

Enzyme assays. To investigate the activity of sucrose synthase enzymes, fruit or leaf samples were collected at different development stages on the basis of fruit length, ranging from 2 to $3 \mathrm{~cm}$ to 18 to $20 \mathrm{~cm}$ in length. SS and SPS were extracted following procedures of Song and Ko (1997). Samples of fresh leaf $(2 \mathrm{~g})$ and freeze-dried fruit tissue $(0.5 \mathrm{~g})$ were homogenized in a prechilled mortar and pestle along with $10 \mathrm{~mL}$ of buffered solution containing $0.4 \mathrm{M}$ Hepes [N-(2-hydroxyethyl) piperazine-N' -(2ethanesulfonic acid)]/KOH buffer ( $\mathrm{pH} 7.5$ ), $20 \mathrm{~mm} \mathrm{MgCl}_{2}, 0.5 \mathrm{~mm}$ phenylmethylsulfonyl fluoride (PMSF), 2 mM ethylenediaminetetraacetic acid, 20\% (v/v) glycerol, 2\% (v/v) ethylene glycol, $20 \mathrm{~mm}$ mercaptoethanol, $20 \mu \mathrm{L}$ aprotinin, and $3 \%(\mathrm{w} / \mathrm{v})$ polyvinylpyrrolidone. The resulting mixture was centrifuged for $5 \mathrm{~min}$ at $13,000 \times \mathrm{g}$, filtered through glasswool, and centrifuged again for $15 \mathrm{~min}$ at $25,000 \times g$. A $2 \mathrm{~mL}$ adjust of supernatant was desalted by passage through a Sephadex G-25 column pre-equilibrated with $20 \mathrm{~mm}$ Hepes/KOH buffer (pH 7.2), $10 \mathrm{~mm} \mathrm{MgCl}_{2}$, $0.1 \mathrm{~mm}$ PMSF, $10 \%$ (v/v) glycerol, and $5 \mathrm{~mm}$ mercaptoethanol. Enzymes were extracted at $4{ }^{\circ} \mathrm{C}$. SPS reactions were initiated by adding $80 \mu \mathrm{L}$ of desalted plant extract to a reaction mixture containing $7.7 \mathrm{~mm}$ fructose-6-P, 
19.3 $\mathrm{mM} \mathrm{MgCl}_{2}, 28.2 \mathrm{~mm}$ glucose-6-P, $7.1 \mathrm{~mm}$ UDP-glucose (uridine $5^{\prime}$-diphosphoglucose), and $62 \mathrm{~mm}$ Hepes/KOH ( $\mathrm{pH} 7.5)$ in a total volume of $240 \mu \mathrm{L}$ as described by Salvucci et al. (1990).

For SS, the reaction consisted of $10 \mathrm{~mm}$ fructose, $5 \mathrm{~mm} \mathrm{MgCl}_{2}, 2 \mathrm{~mm}$ UDP-glucose, $100 \mathrm{~mm}$ Hepes/KOH (pH 7.2), and $80 \mu \mathrm{L}$ plant extract with a final volume of $1 \mathrm{~mL}$. All reactions were carried out at $30{ }^{\circ} \mathrm{C}$. At specific times, reactions were ended by boiling $60-\mu \mathrm{L}$ aliquots for $2 \mathrm{~min}$ and centrifuged at $13,000 \times g$ for $2 \mathrm{~min}$. The reaction mixtures of $50 \mu \mathrm{L}$ were incubated with shaking by addition of $100 \mu \mathrm{L} 30 \%(\mathrm{w} / \mathrm{v}) \mathrm{KOH}$ and placing the tubes in a boiling water bath for $10 \mathrm{~min}$. After cooling, $3 \mathrm{~mL}$ anthrone was added (Hubbard et al., 1989), and the mixtures were incubated at $40{ }^{\circ} \mathrm{C}$ for $15 \mathrm{~min}$. After cooling, color development was measured at $620 \mathrm{~nm}$ and quantified using a standard calibration curve with standards. Sucrose concentration was measured based on the anthrone method of Van Handel (1968). UDP was measured using the method described by Salvucci et al. (1990). Preliminary research indicated that the SS activity in the synthetic direction at $\mathrm{pH} 7.2$ was equivalent to the breakdown activity at an optimum $6.5 \mathrm{pH}$. To make it simple, SS was therefore assayed in the synthetic direction. Protein was determined using the Bio-Rad Protein Kit (Bio-Rad Laboratories, Hercules, CA) through the Coomassie blue method of Bradford (1976). Each experiment was conducted in triplicate and consisted of the combined extracts of three eggplant fruits.

Data analysis. Statistical analysis was performed using procedures of the Statistical Analysis System (SAS Institute, Inc., Cary, NC). When the means were significant at the F-test, the means were separated by a least significant difference test.

\section{Results and Discussion}

Sugar analysis. The concentrations of sucrose, glucose, and fructose in eggplant fruits were measured. Glucose and fructose concentrations were higher than that of sucrose. Glucose and fructose are predominant reducing sugars, but their contents vary with light intensity. Total or individual sugar concentrations were higher in the reflective and white mulches at all developmental stages than the black and transparent mulches. The concentration of each sugar in plants of the four polyethylene mulch treatments increased during all fruit development stages (Fig. 1).

The results suggest that amount of light reflection in the reflective film was the highest and that its light intensity can be uniformly distributed under the plant canopy. This can confirm that difference in sugar composition depends on light intensity variations as affected by different polyethylene mulches. These findings, therefore, suggest that increase in light intensity stimulates the sugar content of eggplant fruits. This study demonstrates that the reflective polyethylene mulches significantly increased sugar concentration. Singh (1992)
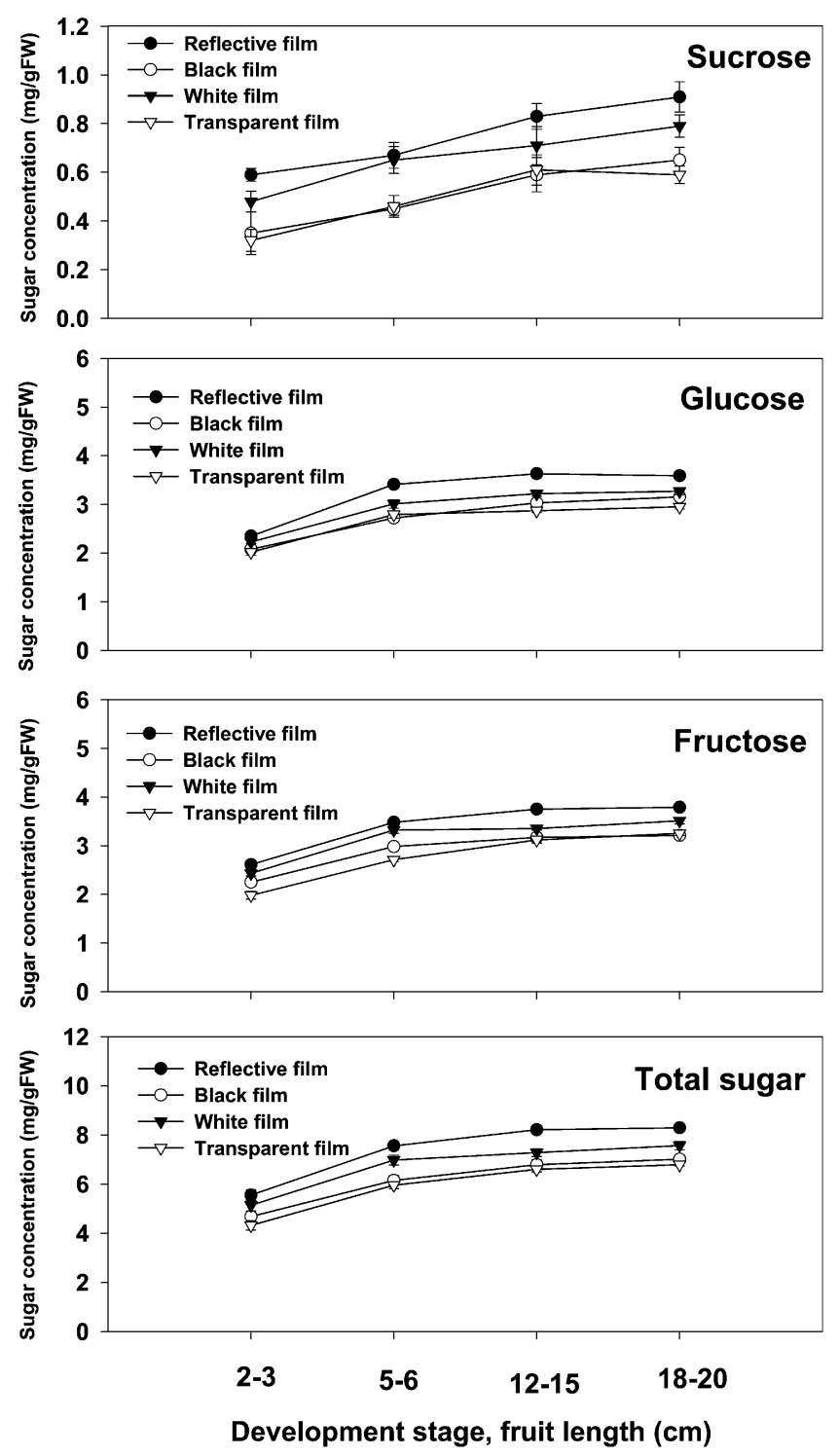

Fig. 1. Changes in contents of sucrose, glucose, and fructose in eggplant fruits during fruit growth with different polyethylene mulches.

discussed the effects of mulching on eggplant, in which the amount of light plays a role in the activities of sucrose-metabolizing enzymes during fruit growth. However, the mechanism by which light stimulates sucrose synthesis of the eggplant fruit is not fully understood.

Enzyme assay. Tables 1 and 2 show the activities of the sucrose-metabolizing enzymes extracted from the leaf and fruit segments. SPS and SS activities increased during the initial fruit development stage and then decreased gradually. Significant differences $(P<0.05)$ in SPS and SS activities among development stages were observed. The reflective film mulch showed the greatest enzyme activity and followed by the white, the black, and transparent mulches. At the four mulching treatments, the activities of SPS and SS are associated with sugar concentrations at the fruit development stages (Table 1; Fig. 1).

SPS and SS activities have been established as the major mechanisms for sucrose synthesis (Huber and Huber, 1996; Stiff and Sonnewald, 1995) and determinants of sink strength (Ho, 1988; Sung et al., 1989). A significant difference in the levels of SPS activity was observed in all treatments during fruit development. Although similar patterns to fruits were observed in leaves, the level of SPS activity was higher in fruit than in leaves of eggplant regardless of development stages or mulches. Throughout all the fruit development stages, SS activity also was consistently higher at the reflective mulch than any other mulch. SS and SPS enzymes affect sucrose metabolism and are associated with developmental processes of the sink organ. In eggplant cultivation, lighting deficiency and low temperature are believed to produce low-quality fruit (Sezgin, 2007). The difference in SS activity is notable, because it indicates higher sink strength during the stages of sugar accumulation. Photosynthetic assimilates produced in leaf chloroplasts are primarily converted into sucrose and starch. Starch accumulated during the photosynthetic period is usually mobilized in the ensuing dark period and can be converted into sucrose for export to other parts of the 
Table 1. Activity of sucrose synthase enzymes in eggplant fruits from plants grown on different mulching materials.

\begin{tabular}{|c|c|c|c|c|c|c|}
\hline \multirow{3}{*}{ Enzyme } & \multirow[b]{3}{*}{ Mulches } & \multicolumn{5}{|c|}{ Developmental stage (fruit length) } \\
\hline & & $2-3 \mathrm{~cm}$ & $5-6 \mathrm{~cm}$ & $12-15 \mathrm{~cm}$ & $18-20 \mathrm{~cm}$ & LSD $(0.05)$ \\
\hline & & \multicolumn{5}{|c|}{ Enzyme activity ( $\mu$ g sucrose/min/mg dry weight) } \\
\hline \multirow[t]{5}{*}{ SPS } & Reflective & $1.59^{\mathrm{z}}$ & 2.68 & 2.77 & 1.85 & 0.58 \\
\hline & White & 1.31 & 2.56 & 2.61 & 1.51 & 0.49 \\
\hline & Black & 1.22 & 2.48 & 2.43 & 1.37 & 0.33 \\
\hline & Transparent & 1.11 & 2.53 & 2.35 & 1.45 & 0.35 \\
\hline & $\operatorname{LSD}(0.05)^{\mathrm{y}}$ & 0.29 & $\mathrm{NS}^{\mathrm{x}}$ & 0.32 & 0.40 & \\
\hline \multirow[t]{5}{*}{ SS } & Reflective & 1.68 & 2.62 & 2.48 & 2.28 & 0.56 \\
\hline & White & 1.50 & 2.60 & 2.39 & 2.18 & 0.65 \\
\hline & Black & 1.52 & 2.42 & 2.24 & 1.66 & 0.62 \\
\hline & Transparent & 1.35 & 2.28 & 2.01 & 1.59 & 0.51 \\
\hline & LSD $(0.05)$ & 0.33 & 0.16 & NS & 0.61 & \\
\hline
\end{tabular}

${ }^{\mathrm{z}}$ Values are the mean of three replicates.

${ }^{y}$ Means were separated by LSD (least significant difference) test $(P<0.05)$.

${ }^{x} \mathrm{NS}=$ nonsignificant.

SPS = sucrose phosphate synthase; $\mathrm{SS}=$ sucrose synthase

Table 2. Activity of sucrose synthase enzymes in eggplant leaves from plants grown on different mulching materials.

\begin{tabular}{llccccc}
\hline & & \multicolumn{5}{c}{ Developmental stage (fruit length) } \\
\cline { 3 - 6 } Enzyme & Mulches & $2-3 \mathrm{~cm}$ & $5-6 \mathrm{~cm}$ & $12-15 \mathrm{~cm}$ & $18-20 \mathrm{~cm}$ & LSD (0.05) \\
\cline { 3 - 6 } SPS & Reflective & $0.48^{\mathrm{z}}$ & 0.56 & 0.52 & 0.51 & NS \\
& White & 0.39 & 0.52 & 0.49 & 0.47 & 0.07 \\
& Black & 0.33 & 0.44 & 0.50 & 0.41 & 0.10 \\
& Transparent & 0.35 & 0.53 & 0.49 & 0.43 & 0.09 \\
& LSD (0.05) & 0.07 & NS & NS & 0.06 & 0.06 \\
SS & Reflective & 0.30 & 0.47 & 0.46 & 0.44 & 0.11 \\
& White & 0.28 & 0.41 & 0.42 & 0.39 & 0.08 \\
& Black & 0.31 & 0.40 & 0.36 & 0.35 & 0.09 \\
& Transparent & 0.26 & 0.45 & 0.33 & 0.40 & 0.10 \\
\end{tabular}

${ }^{\mathrm{z}}$ Values are the mean of three replicates.

${ }^{y}$ Means were separated by LSD (least significant difference) test $(P<0.05)$.

NS = nonsignificant.

SPS $=$ sucrose phosphate synthase; $\mathrm{SS}=$ sucrose synthase .

plant. Sucrose synthesized in the leaf is loaded onto the phloem sap and partitioned to other parts of the plant through the vesicular system. In sucrose-importing organs, the regulation of sucrose cleavage within the cells serves as the biochemical marker of sink strength (Ho, 1988; Sung et al., 1989). In this study, the change in SPS and SS activities were slightly associated with fruit growth (Tables 1 and 2). The regulation of SS activity may be less important compared with SPS activity in inducing fruit growth. Although both SS and SPS are sucrose synthetic enzymes, their activities appear to vary among fruit species. In pineapple and papaya fruits, SPS is actively involved in sucrose synthesis, whereas SS is known to be involved in sucrose cleavage rather than synthesis (Chen and Paull, 2000; Zhou and Paull, 2001).

This study determines the possible causes of unequal sugar distribution in eggplant fruits by examining the allocation of enzymes as the determinant of sink strength and sucrose synthesis. Sink strength at the enzyme level refers to the series of enzymatic reactions associated with sucrose storage or its interconversion. Sugar concentration in eggplant fruit was studied with focus on the regulation of sucrose and sink strength. For eggplants cultured with high canopy density, the uniform lighting stimulated by reflective mulch affects the
Claussen, W., B.R. Loveys, and J.S. Hawker. 1986. Influence of sucrose and hormones on the activity of sucrose synthase and invertase in detached leaves and leaf sections of eggplant (Solanum melongena). J. Plant Physiol. 124:345-357.

Costello, M.J. 1995. Spectral reflectance from a broccoli crop with vegetation or soil as background: Influence on immigration by Brevicoryne brassicae and Myzus persicae. Entomol. Exp. Appl. 75:109-118.

Decoteau, D.R., M.J. Kasperbaner, and P.G. Hunt 1990. Bell pepper plant development over mulches of diverse colors. HortScience 25:460-462.

Ho, L.C. 1988. Metabolism and compartmentation of imported sugars in sink organs in relation to sink strength. Annu. Rev. Plant Physiol. 39:355-378.

Hubbard, N.L., S.C. Huber, and D.M. Pharr. 1989. Sucrose phosphate synthase and acid invertase as determinants of sucrose concentration in developing muskmelon (Cucumis melo L.) fruits. Plant Physiol. 91:1527-1534.

Huber, S.C. and J.L. Huber. 1996. Role and regulation of sucrose phosphate synthase in higher plants. Annu. Rev. Plant Physiol. Plant Mol. Biol. 47:431-444.

Islam, M.S., T. Matsui, and Y. Yoshida. 1996. Carbohydrate content and the activities of sucrose synthase, sucrose phosphate synthase and acid invertase in different tomato cultivars during fruit development. Sci. Hort. 65:125-136.

Kim, Y.C., K.Y. Kim, K.W. Park, H.K. Yun, T.C. Seo, J.W. Lee, and S.G. Lee. 2003. Influence of silicate application on the sucrose synthetic enzyme activity of tomato in perlite media culture. Journal of Korea Societies HortScience 44:172176.

Krug, H. 1991. Gemuse production. Verlag Paul Parey, Berlin and Hamburg, Germany.

Messiaen, C.M. 1989. Le potager tropical. Press Univ. de France, Paris, France.

Orzolek, M.D. and J.H. Murphy. 1993. The effect of colored polyethylene mulch on the yield of squash and pepper. Proc Natl Acad Sci U S A 24:157-161.

Porter, W.C. and W.W. Etzell. 1982. Effects of aluminium-painted mulch and black polyethylene mulches on bell pepper, Capsicum annuum L. HortScience 17:942-943.

Although this study defines the possible ad vantages of sucrose-metabolizing enzymes by using different mulching materials in eggplant culture, it clearly showed the benefits derived from using reflective mulch in eggplant. Additional work is recommended to clarify the range of benefits and modes of action associated with different mulching materials.

\section{Literature Cited}

Albregts, E.E. and C.K. Chandler. 1992. Effect of polyethylene mulch colour on the fruiting response of strawberry. Proc. Soil Crop Sci. Soc. Fla. 52:40-43.

Balibrea, M.E., A.M. Santa Cruz, M.C. Bolarin, and F. Perez-Alfocea. 1996. Sucrolytic activities in relation to sink strength and carbohydrate composition in tomato fruit growing under salinity. Plant Sci. 118:47-55.

Bradford, M.M. 1976. A rapid and sensitive method for the quantitation of microgram quantities of protein using the principle of dye binding. Anal. Biochem. 72:143-147.

Brown, J.E., W.D. Goff, J.M. Dangler, W. Hogue, and M.S. West. 1992. Plastic mulch colour inconsistently affects yield and earliness of tomato. HortScience 27:1135.

Chen, C.C. and R.E. Paull. 2000. Sugar metabolism and pineapple flesh translucency. J. Amer. Soc. Hort. Sci. 125:558-562.
Salvucci, M.E., R.R. Drake, and B.E. Haley. 1990. Purification and photoaffinity labeling on sucrose phosphate synthase from spinach leaves. Arch. Biochem. Biophys. 281:212-218.

Sezgin, U. 2007. Effect of light and temperature on the phenology and maturation of the fruit of eggplant (Solanum melongena) grown in greenhouses. N. Z. J. Crop Hort. Sci. 35:51-59.

Singh, S.P. 1992. Studies on mulching of vegetable crops. Advances in Horticulture and Forestry 2:115-143

Song, K.J. and K.C. Ko. 1997. Relationship between sugar content and sucrose synthase activity in orange fruits. J. Korean Stat. Soc. 38:242-245.

Stiff, M. and U. Sonnewald. 1995. Regulation of metabolism in transgenic plants. Annu. Rev. Plant Physiol. Plant Mol. Biol. 46:341-368.

Sung, S.S., W.J. Sheih, D.R. Geiger, and C.C. Black. 1994. Growth, sucrose synthase, and invertase activities of developing phaseolus vulgaris L. fruits. Plant Cell Environ. 17:419-426.

Sung, S.S., D.P. Xu, and C.C. Black. 1989. Identification of actively filling sucrose sinks. Plant

Van Handel, E. 1968. Direct microdetermination of sucrose. Anal. Biochem. 22:280-283.

Zhou, L. and R.E. Paull. 2001. Sucrose metabolism during papaya (Carica papaya) fruit growth and ripening. J. Amer. Soc. Hort. Sci. 126:351357. Physiol. 89:1117-1121. 